\title{
Neoplastic Plasma Cells 20 Percent or Less of Bone Marrow Nucleated Cells
}

National Cancer Institute

\section{Source}

National Cancer Institute. Neoplastic Plasma Cells 20 Percent or Less of Bone Marrow

Nucleated Cells. NCI Thesaurus. Code C150709.

A semi-quantitative microscopic finding indicating that 20 percent or less of the nucleated cells in a bone marrow sample are neoplastic plasma cells. 